\author{
산머루주 박 급여가 버크셔종의 등심 품질특성에 미치는 영향 \\ 김태완* · 김철욱** . 김일석** \\ (사)경남양돈클러스터사업단*, 진주산업대학교 동물소재공학과**
}

\title{
Effects of Supplementary Wild Grape Wine By-product on Quality Characteristic of Loin from Berkshire Breed
}

\author{
Tae Wan, Kim*, Chul Wook, Kim** and Il Suk, Kim** \\ Gyeongnam Swine Cluster Agency* \\ Department of Animal Resource Technology, Jinju National University**
}

\begin{abstract}
A total of 40 pigs were used to investigate the feeding effects of supplementary wild grape wine by-product on pork quality of American Berkshire breed in the swine farm of Hamyang area. Treatments were $\mathrm{C}$ that was basal diet, and $\mathrm{T}$ that was treated by dietary wild grape wine by-product (5\%) were added in feed. About $70 \mathrm{~kg}$ pigs were bred a period of 88 days, and slaughtered. The pork quality characteristic were measured in pork loin. In chemical composition, moisture and crude fat were not significantly different between $\mathrm{C}$ and $\mathrm{T}$, but $\mathrm{T}$ were lower $(\mathrm{p}<0.05)$ than $\mathrm{C}$. There were no difference in crude protein and crude ash $(\mathrm{p}<0.05)$. $\mathrm{pH}$ and water holding capacity (WHC) were not significantly different between $C$ and $T$, whereas the cholesterol and fat shear force of $T$ were lower $(p<0.05)$ than $C$. There were no different in the meat color, but the Hunter's $L^{*}$ and $W$ value of $T$ were higher $(p<0.05)$ than $C$. Oleic acid $\left(\mathrm{C}_{18: 1}\right)$, linoleic acid $\left(\mathrm{C}_{18: 2}, \mathrm{n}-6\right)$, arachidonic acid $\left(\mathrm{C}_{20: 4}, \mathrm{n}-6\right)$, Essential fatty acid $(\mathrm{EFA})$, and EFA/unsaturated fatty acid were significantly $(\mathrm{p}<0.05)$ different between $\mathrm{C}$ and $\mathrm{T}$, in the fatty acid compositions of loins. Also, the total amino acid composition of pork were not significantly different between $\mathrm{C}$ and $\mathrm{T}$, but essential fatty acid of $\mathrm{T}$ was significantly higher $(\mathrm{p}<0.05)$ than that of $\mathrm{C}$. This observation suggests that wild grape wine by-product supplements may have some beneficial effects on improving backfat color, shear force, cholesterol and essential fatty acid content of pork loin.
\end{abstract}

(Key words : Wild grape wine by-product, Pork quality characteristics)

\section{I. 서 론}

우리나라는 경제발전에 의한 소득증대로 식 육류의 소비가 점차 증가하고 있으며, 돼지고 기는 연간 1 인당 소비량이 주요 축산물의 절반 이상을 차지하고 있는 가운데, 소비자들은 돼 지고기 구입 시 안전성과 위생성을 최우선으로 하고 다음으로 맛과 기능성을 고려하는 것으로 분석되어(이 등, 2005), 건강지향적인 돈육에 대
한 선호도가 점차 증가하고 있음을 보여주고 있다.

최근 들어 소비자들의 육질에 대한 인식이 높아지면서 품질이 우수하다고 알려진 재래돼 지나 가고시마 및 미국산 버크셔 종 흑모색 돼 지에 대한 관심도가 점차 증대되고 있다. 일반 적으로 돼지고기는 육색이 옅고 조직이 부드러 우며 성분에 있어서도 단백질의 아미노산 조성 도 필수아미노산이 많이 포함되어 있으며, 특

Corresponding author : I. S. Kim, Department of Animal Resources Technology, Jinju National University, Jinju, 660-758, Korea.

Tel : 055-751-3288, Fax : 82-055-751-3280, E-mail : iskim@jinju.ac.kr 
히 비타민 B1의 함량은 쇠고기나 닭고기의 거 의 10 배에 달해 비타민 $\mathrm{B} 1$ 의 공급원으로서도 알려져 있다(농촌진흥청, 1991). Lee 등 (2005) 은 재래종 돼지고기의 조단백질과 조지방 함량 은 개량종 돼지고기보다 높았고 수분 함량과 조회분 함량은 낮았다는 보고하였으며, $\mathrm{Kim}$ 등 (2000)은 도축 45분 후 버크셔 품종이 다른 품 종의 돈육에 비해 보수력이 높았다고 하였다. Jeremiah 등 (1999)은 듀록, 햄프셔, 랜드레이스, 요크셔 등 네 가지 품종 중에서 듀록종이 근육 조직과 근육 내 지방 함량이 가장 높은 점수를 얻었다고 하였고, Lan 등 (1993)은 요크셔종이 메산종보다 배최장근 단면적이 더 높았고, 이 원교잡종은 요크셔종과 메산종의 중간 정도였 으며, 요코셔종은 근내지방도가 가장 높았다고 하였다. Jin 등 (2006)은 아미노산 조성에서 glycine, alanine, cystine, valine, leucine, tyrosine, histidine, lysine 및 arginine은 $\mathrm{LY} \times \mathrm{D}$ 품종이 영 국계 및 가고시마 버크셔보다 높게 나타났고, aspartic acid, threonine, serine, glutamic 및 phenylalanine은 가고시마 버크셔종에서 많았다 고 하였다.

술을 만들고 남은 미량의 알코올과 다량의 효소, 효모가 포함되어 있어 소화흡수가 잘 되 는 것으로 알려진 주박 (酒粕; 술지게미)은 돼 지고기 특유의 냄새를 없애고 식감을 개선시킨 다 (원 등, 2006). 특히 머루주는 포도주보다 산 미가 강하면서 안토시아닌 함량과 페놀성분이 많이 함유된 것으로 알려져 있다 (Kim, 1996). 폴리페놀 물질들은 항균, 항산화 및 항염증 작 용, 심장병 예방, 암세포 성장 억제 등 다양한 생리활성 기능을 가지고 있으며 (Joe et al., 2002), 타르타닉산 및 탄닌의 항균작용이 있는 것으로 알려져 있을 뿐만 아니라 (Beuchat와 Golden, 1989) 머루주박을 사료로 이용한 돈육 은 콜레스테롤 함량을 저하시키는 효과가 있 고, 감량이 적어 가공하였을 때는 수율을 향상 시킬 수 있으며, 염용성 단백질의 추출성이 높 아 가공성이 좋다고 하였다 (정과 문, 2005).

본 연구에서는 머루주 생산에 따라 발생하는 부산물을 사료에 첨가하여 브랜드 돈육 생산을 위한 기초 자료를 얻고자 실시되었다.

\section{ㅍ. 재료 및 방법}

\section{1. 공시동물 및 사양관리}

시험에 사용되는 공시동물은 미국산 버크셔 종 20 두에 대해 머루주박 부산물을 $5 \%$ 첨가하 여 급여하고, 일반 배합사료만을 급여하는 20 두를 대조구로 배치하여 제한급여를 하면서 88 일간 사양실험을 하였다. 시험사료는 수분 $18.21 \%$, 조단백 $12.41 \%$, 조지방 $3.05 \%$, 조섬유 $5.19 \%$, 조회분 $5.05 \%$, 가용무질소물 (NFE)는 $56.08 \%$ 로 구성되었으며, 총 에너지 (total energy) 는 $3961.61 \mathrm{cal} / \mathrm{g}$ 이었다. 또한 사료의 지방산 조 성은 myristic acid $\left(\mathrm{C}_{14: 0}\right) \quad 0.12 \%$, palmitic acid $\left(\mathrm{C}_{16: 0}\right) \quad 16.15 \%$, palmitoleic acid $\left(\mathrm{C}_{16: 1}\right) \quad 0.23 \%$, heptadecanoic $\operatorname{acid}\left(\mathrm{C}_{17: 0}\right) \quad 0.09 \%$, strearic acid $\left(\mathrm{C}_{18: 0}\right) \quad 2.21 \%$, oleic acid $\left(\mathrm{C}_{18: 1}\right) \quad 27.14 \%$ 및 linoleic acid $\left(\mathrm{C}_{18: 2}\right) \quad 54.05 \%$ 로 구성되었고, 포화 지방산 (saturated fatty acids)은 $18.57 \%$, 불포화 지방산 (unsaturated fatty acids)은 $81.42 \%$ 이었으 며, 필수지방산 (essential fatty acids)은 $54.05 \%$ 이 었다.

사료는 일일두당 $2.7 \mathrm{~kg}$ 이내로 제한급여를 하였으며, 물은 자동급수기로 자유로이 섭취할 수 있도록 하였으며 나머지 사양관리는 관행법 에 준하여 실시하였다.

\section{2. 실험항목 및 방법}

(1) 공시재료

도축 후 24 시간 냉장실 $\left(0 \sim 1 \pm 2{ }^{\circ} \mathrm{C}\right)$ 에서 냉각 한 후 좌반도체의 등심 (longissimus dorsi muscle)을 분할 정형 및 랩 포장하여 이송한 후, $0 \pm 1^{\circ} \mathrm{C}$ 온도에서 1 일 경과 후 육질분석을 위해 공시하였다.

(2) 품질분석

1) 일반성분

AOAC (1990) 방법에 따라 수분은 건조법, 조 단백질 함량은 Micro kjeldahle 방법, 조지방 함 량은 Soxhlet 추출법 및 조회분 함량은 전기회 화로를 이용하여 측정하였다. 


\section{2) $\mathbf{p H}$}

근막, 지방 등을 제거한 후 세절한 시료 10 $\mathrm{g}$ 을 증류수 $90 \mathrm{~mL}$ 와 함께 균질기 (T25B, IKA Sdn. Bhd., Malaysia)로 13,500 rpm에서 10간 균 질하여 $\mathrm{pH}$-meter (8603, Metrohm, Swiss)로 측정 하였다.

\section{3) 전단가}

Instron 3343 (US/MX50, A\&D Co., USA)을 이용하여 비가열 시료를 가로로 눕혀 knife형 plunger로 측정하였다.

\section{4) 콜레스테롤}

시료를 Folch 등 (1957)의 방법으로 조지방을 추출한 다음 추출한 지질 $0.1 \mathrm{~g}$ 에 saponification 시약 $(30 \% \mathrm{KOH}$ : Ethanol = 9:1) $5 \mathrm{~mL}$ 와 internal standard (5a-cholestane $0.5 \mathrm{mg}) 1 \mathrm{~mL}$ 넣고 균질 화 하여 뚜껑을 닫은 다음 $60^{\circ} \mathrm{C}$ 항온수조에서 1 시간 동안 반응시킨다. 냉각 후에 증류수 5 $\mathrm{mL}$ 와 hexane $8 \mathrm{~mL}$ 씩 넣고 혼합한 다음 층이 분리될 때까지 실온에서 방치하였다. 상층액을 회수한 다음 질소가스를 이용하여 완전히 건조 시키고 pyridine $200 \mu \mathrm{l}$ 와 sylon BFT $100 \mu \mathrm{l}$ 를 넣 고 천천히 섞은 다음 $\mathrm{GC}$ 에 주입하여 콜레스테 롤을 분리 정량하였으며, 이때 $\mathrm{GC}$ 조건은 Table 1 과 같다.

5) 육색 및 지방색

육색은 등심근 단면적의 전 부위를 균일하게 측정하였고, 지방색은 등심에 붙어있는 등지방 부위를 Chromameter (CR-400, Minolta Co., Japan) 로 동일한 시료에 대해 9회 반복하여 명도 (lightness)를 나타내는 $\mathrm{L}$ *값, 적색도(redness)를
나타내는 a*값 및 황색도(yellowness)를 나타내 는 $\mathrm{b}^{*}$ 값을 Hunter값으로 측정하였으며, 이때 표 준색판은 $\mathrm{L}^{*}=89.2, \mathrm{a}^{*}=0.921, \mathrm{~b}^{*}=0.783$ 이었다.

\section{(6) 지방산 및 아미노산 조성}

지방산 조성은 시료 $10 \mathrm{~g}$ 을 Folch 등 (1957)의 방법으로 조지방을 추출하고, 추출된 조지방 시료에 chloroform $1 \mathrm{~mL}$ 를 넣어 녹인 다음, 이 중 $100 \mu \mathrm{l}$ 를 취하여 $20 \mathrm{~mL}$ tube에 넣는다. 이때 $1 \mathrm{~mL}$ 의 methylation (methanolic-HCl-3 N) 시약을 넣고 항온수조에서 $60^{\circ} \mathrm{C}$ 로 40 분간 반응시킨다. 반응이 끝난 후 방냉시키고, hexane $3 \mathrm{~mL}$ 와 증 류수 $8 \mathrm{~mL}$ 를 넣고 강하게 섞어준 다음 시료를 24 시간 방치하여 층분리시키고 상층액 중 $1 \mu \mathrm{l}$ 를 주입하여 GC(HP 6890, Tekmar Precert, Agilent Co., USA)로 분석하였다.

아미노산 조성은 AOAC (1990) 방법에 따라 시료 약 $0.02 \mathrm{~g}$ 에 $6 \mathrm{~N} \mathrm{HCl} 15 \mathrm{~mL}$ 를 가하여, 110 ${ }^{\circ} \mathrm{C}$ dry oven에서 24시간 이상 동안 산가수분해 한 후 $55^{\circ} \mathrm{C}$ Water bath에서 감압 농축하여 $\mathrm{pH}$ 2.20 sodium citrate buffer로 $25 \mathrm{~mL}$ Volumetric flask에 정용하여 아미노산자동분석기 (Biochrom 20, Pharm Tek, England)를 이용하였다.

\section{3. 통계분석}

이상의 실험에서 얻어진 결과는 SAS (1999) 의 GLM (General linear model) 방법으로 분석하 고, 처리 간 평균의 비교를 위해 Duncan의 Multiple range test를 사용하였다.

Table 1. GLC(Shimadzu GC-17A) conditions for analysis of cholesterol content

\begin{tabular}{ll}
\hline \multicolumn{1}{c}{ Items } & \multicolumn{1}{c}{ Conditions } \\
\hline \hline Column & SAC-5 column \\
& $30 \mathrm{~m} \times 0.25 \mathrm{~mm} \mathrm{ID,} 0.25 \mu \mathrm{m}$ film \\
& Initial temp,; $265^{\circ} \mathrm{C}$, Final temp.; $280^{\circ} \mathrm{C}$, Injector temp.; $300^{\circ} \mathrm{C}$ \\
& Detector temp.; $300^{\circ} \mathrm{C}$. Programming rate $: 4^{\circ} \mathrm{C} / \mathrm{min}$ \\
Detector & Flame Ionization Detector \\
Carrier gas & He \\
Flow rate & $20 \mathrm{~cm} / \mathrm{sec}$ \\
Split ratio & $100: 1$ \\
\hline
\end{tabular}




\section{III. 결과 및 고찰}

\section{1. 일반성분}

산머루주 부산물의 급여에 따른 일반성분 분 석 결과를 Table 2에 나타내었다.

수분 및 조지방 함량은 대조구와 처리구 간 에 유의적인 차이가 없었으나 $(\mathrm{p}>0.05)$, 조단백 질과 조회분 함량은 대조구에 비해 처리구가 유의적으로 낮게 나타났다 $(\mathrm{p}<0.05)$.

\section{2. 이화학적 특성 및 콜레스테롤 함량}

산머루주 부산물의 급여에 따른 $\mathrm{pH}$, 보수력, 전단가 및 콜레스테롤 함량 분석 결과를 Table 3 에 나타내었다.

$\mathrm{pH}$, 보수력 (WHC)은 대조구와 처리구 간에 유의적인 차이가 없었으며 ( $\mathrm{p}>0.05)$, 콜레스테롤 함량 및 지방 전단가는 대조구에 비해 처리구 가 유의적으로 낮게 나타났다 $(\mathrm{p}<0.05)$. 돼지고 기는 쇠고기에 비하여 콜레스테롤 함량이 낮으 며(Wood 등, 1999), 산머루 부산물 급여에 따라
콜레스테롤 함량이 크게 떨어지는 것은 머루와 같은 종에 속하는 포도껍질과 씨에 섬유질, tocopherol, catechin류, polyphenol 화합물, tannin 등이 다량 함유되어 있어서 (Renaude와 Lorgeril, 1992) 이들 성분들이 콜레스테롤 함량을 낮추 는 것으로 보고되었다 (정과 문, 2005). 음식으 로부터 섭취한 지방질은 간에서 콜레스테롤로 전환되며, 이 콜레스테롤은 몸의 세포를 형성 하는데 작용할 뿐만 아니라 호르몬의 역할에 관여하는 물질로써 인체 내에 없어서는 안 되 는 중요한 구성성분이다. 이러한 콜레스테롤은 인체 내의 중요한 구성성분임에도 불구하고, 혈액 내에 콜레스테롤 함량이 계속적으로 증가 하면 콜레스테롤은 혈관 벽에 쌓이게 되며, 혈 액의 흐름을 방해하여 고혈압, 동맥경화, 심장 마비, 중풍 등과 같은 혈관계 질환의 원인으로 작용하게 된다 (Jung 등, 2003).

\section{3. 육색 및 지방색}

산머루주 부산물의 급여에 따른 육색 및 지 방색 분석 결과를 Table 4에 나타내었다.

Table 2. Effect of feeding wild grape wine by-product on proximate compositions (\%) of loin in American Berkshire

\begin{tabular}{ccccc}
\hline Treatments $^{1)}$ & Moisture & Crude protein & Crude fat & Crude ash \\
\hline \hline $\mathrm{C}$ & 73.19 & $22.23^{\mathrm{A}}$ & 3.31 & $1.24^{\mathrm{A}}$ \\
$\mathrm{T}$ & 73.24 & $20.99^{\mathrm{B}}$ & 3.31 & $1.07^{\mathrm{B}}$ \\
$\mathrm{SE}^{2)}$ & 0.37 & 0.38 & 0.30 & 0.05 \\
\hline
\end{tabular}

1) C: $0 \%$ of wild grape wine by-product, $\mathrm{T} ; 5 \%$ of wild grape wine by-product.

2) Pooled standard error $(n=3)$.

A-B Means with different superscripts in the same column significantly differ at $\mathrm{p}<0.05$.

Table 3. Effect of feeding wild grape wine by-product on $\mathrm{pH}$, WHC, fat shear force and cholesterol of loin in American Berkshire

\begin{tabular}{ccccc}
\hline Treatments $^{1)}$ & $\mathrm{pH}$ & WHC(\%) & Cholesterol(mg/100g) & Fat \\
\hline \hline $\mathrm{C}$ & 5.37 & 77.88 & $57.80^{\mathrm{A}}$ & $16.91^{\mathrm{A}}$ \\
$\mathrm{T}$ & 5.43 & 73.97 & $37.16^{\mathrm{B}}$ & $8.51^{\mathrm{B}}$ \\
$\mathrm{SE}^{2)}$ & 0.05 & 2.96 & 3.95 & 1.44 \\
\hline
\end{tabular}

1) Treatments are the same as in Table 2.

2) Pooled standard error $(\mathrm{n}=3)$.

A-B Means with different superscripts in the same column significantly differ at $\mathrm{p}<0.05$. 
Table 4. Effect of feeding wild grape wine by-product on meat and fat color of loin in American Berkshire

\begin{tabular}{|c|c|c|c|c|c|c|c|c|}
\hline \multirow{2}{*}{ Treatments ${ }^{1)}$} & \multicolumn{4}{|c|}{ Meat color } & \multicolumn{4}{|c|}{ Fat color } \\
\hline & $\mathrm{L}^{*}$ & $a^{*}$ & $\mathrm{~b}^{*}$ & $\mathrm{~W}^{3)}$ & $\mathrm{L}^{*}$ & $a^{*}$ & $\mathrm{~b}^{*}$ & $\mathrm{~W}$ \\
\hline $\mathrm{C}$ & 53.25 & 10.61 & -0.39 & 54.42 & $77.16^{\mathrm{B}}$ & 6.95 & -1.80 & $82.55^{\mathrm{B}}$ \\
\hline $\mathrm{T}$ & 53.48 & 12.64 & -0.34 & 54.49 & $79.40^{\mathrm{A}}$ & 6.71 & -2.60 & $87.20^{\mathrm{A}}$ \\
\hline $\mathrm{SE}^{2)}$ & 1.03 & 0.73 & 0.55 & 1.38 & 0.38 & 0.28 & 0.29 & 1.12 \\
\hline
\end{tabular}

1) Treatments are the same as in Table 2.

2) Pooled standard error $(n=3)$.

3) $\mathrm{W}=\mathrm{L}^{*}-3 \mathrm{~b}^{*}$.

A-B Means with different superscripts in the same column significantly differ at $\mathrm{p}<0.05$.

육색의 명도( $\left.\mathrm{L}^{*}\right)$, 적색도 $\left(\mathrm{a}^{*}\right)$, 황색도(b*) 및 백색도(W) 모두 처리 간에 유의적인 차이가 없 었고( $>0.05)$, 지방색의 적색도와 황색도는 처 리 간에 유의적인 차이가 없었으나 $(\mathrm{p}>0.05)$, 명 도와 백색도는 대조구에 비해 처리구가 유의적 으로 높게 나타났다 $(\mathrm{p}<0.05)$. 이러한 식육의 색 깔은 대부분의 myoglobin과 일부 hemoglobin에 의존하는데(한 등, 1994), 머루에 붉은 색을 띄 는 anthocyanin이 함유되어 있고(Hwang과 Ahn, 1975), 이것이 사료를 통하여 근육에 침착되어
머루주박을 급여한 돈육 및 지방의 색깔이 더 붉어진다고 한 보고(정과 문, 2005)와는 달리 본 연구에서는 육색 및 지방색의 적색도에는 유의적인 차이가 없었다.

\section{4. 지방산 조성}

산머루주 부산물의 급여에 따른 지방산 조성 분석 결과를 Table 5에 나타내었다.

미리스트산, 팔미트산, 팔미톨레산, 스테아르

Table 5. Effect of feeding wild grape wine by-product on fatty acid composition (\%) of loin in American Berkshire

\begin{tabular}{lccc}
\hline \multirow{2}{*}{ Fatty acids } & \multicolumn{2}{c}{ Treatments $^{1)}$} & \multirow{2}{*}{ SE $^{2)}$} \\
\cline { 2 - 3 } & \multicolumn{1}{c}{$\mathrm{C}$} & 0.69 & 0.10 \\
\hline \hline Myristic acid $\left(\mathrm{C}_{14: 0}\right)$ & 0.76 & 18.90 & 0.20 \\
Palmitic acid $\left(\mathrm{C}_{16: 0}\right)$ & 18.65 & 2.60 & 0.31 \\
Palmitoleic acid $\left(\mathrm{C}_{16: 1}\right)$ & 2.86 & 7.95 & 0.21 \\
Stearic acid $\left(\mathrm{C}_{18: 0}\right)$ & 7.80 & $42.32^{\mathrm{A}}$ & 0.27 \\
Oleic acid $\left(\mathrm{C}_{18: 1}\right)$ & $40.22^{\mathrm{B}}$ & $18.87^{\mathrm{B}}$ & 0.30 \\
Linoleic acid $\left(\mathrm{C}_{18: 2, \mathrm{n}-6}\right)$ & $23.41^{\mathrm{A}}$ & $8.68^{\mathrm{A}}$ & 0.33 \\
Arachidonic acid $\left(\mathrm{C}_{20: 4,} \mathrm{n}-6\right)$ & $6.31^{\mathrm{B}}$ & 27.53 & 0.32 \\
Saturated fatty acid & 27.21 & 72.47 & 0.32 \\
Unsaturated fatty acid & 72.79 & $27.55^{\mathrm{B}}$ & 0.51 \\
Essential fatty acid & $29.72^{\mathrm{A}}$ & 2.63 & 0.04 \\
UFA/SFA & 2.68 & $0.38^{\mathrm{B}}$ & 0.01 \\
EFA/UFA & $0.41^{\mathrm{A}}$ &
\end{tabular}

1) Treatments are the same as in Table 2.

2) Pooled standard error $(\mathrm{n}=3)$.

A-B Means with different superscripts in the same column significantly differ at $\mathrm{p}<0.05$. 
산, 포화지방산(SFA), 불포화지방산 (UFA) 및 UFA/SFA 비율은 처리 간에 유의적인 차이가 없었으며, 리놀레산, 필수지방산(EFA) 및 $\mathrm{EFA}$ UFA 비율은 대조구에 비해 처리구가 낮게 나 타났으나 올레산과 아라키돈산은 반대로 대조 구에 비해 처리구가 높게 나타났다 $(\mathrm{p}<0.05)$.

5. 아미노산 조성

산머루주 부산물의 급여에 따른 아미노산 조
성 분석 결과를 Table 6에 나타내었다.

Flavorous amino acid, sweet taste amino acid, aromatic amino acid, total amino acid 등은 처리 간에 유의적인 차이가 없었으며 ( $\mathrm{p}>0.05)$, 세린, 히스티딘, 아르기닌, 쓴맛 관련 아미노산 (bitter amino acid) 및 필수아미노산 (essential amino acid)은 대조구에 비해 처리구가 높게 나타난 반면, 알기닌은 처리구가 낮게 나타났다 $(\mathrm{p}<$ $0.05)$.

Table 6. Effect of feeding wild grape wine by-product on amino acid compositions (\%) of loin in American Berkshire

\begin{tabular}{|c|c|c|c|}
\hline \multirow{2}{*}{ Amino acids } & \multicolumn{2}{|c|}{ Treatments $^{1)}$} & \multirow{2}{*}{$\mathrm{SE}^{2)}$} \\
\hline & $\mathrm{C}$ & $\mathrm{T}$ & \\
\hline Aspartic acid & 2.08 & 2.21 & 0.06 \\
\hline Threonine $^{4)}$ & 1.00 & 1.06 & 0.03 \\
\hline Serine $^{4)}$ & $0.75^{\mathrm{B}}$ & $0.86^{\mathrm{A}}$ & 0.03 \\
\hline Glutamic acid ${ }^{3)}$ & 3.37 & 3.32 & 0.01 \\
\hline Proline & 0.77 & 0.80 & 0.04 \\
\hline Glycine $^{4)}$ & 0.84 & 0.93 & 0.03 \\
\hline Alanine $^{4)}$ & $1.19^{\mathrm{A}}$ & $0.84^{\mathrm{B}}$ & 0.04 \\
\hline Valine $^{677)}$ & 1.11 & 1.25 & 0.05 \\
\hline Isoleucine $^{6) 7)}$ & 1.05 & 1.14 & 0.04 \\
\hline Leucine $^{7)}$ & 1.75 & 1.81 & 0.06 \\
\hline Tyrosine $^{5) 6)}$ & 0.78 & 0.79 & 0.03 \\
\hline Phenylalanine ${ }^{5) 677)}$ & 0.85 & 0.89 & 0.03 \\
\hline Histidine $^{7)}$ & $0.98^{\mathrm{B}}$ & $1.17^{\mathrm{A}}$ & 0.04 \\
\hline Lysine $^{7)}$ & 1.73 & 2.01 & 0.15 \\
\hline Arginine $^{7)}$ & $1.20^{\mathrm{B}}$ & $1.56^{\mathrm{A}}$ & 0.05 \\
\hline Flavorous amino acid ${ }^{3)}$ & 3.37 & 3.32 & 0.10 \\
\hline Sweet taste amino acid ${ }^{4}$ & 3.78 & 3.69 & 0.12 \\
\hline Aromatic amino acid ${ }^{5)}$ & 1.63 & 1.67 & 0.05 \\
\hline Bitter amino acid $^{6}$ & $5.97^{\mathrm{B}}$ & $6.80^{\mathrm{A}}$ & 0.18 \\
\hline Essential amino acid ${ }^{7)}$ & $9.67^{\mathrm{B}}$ & $10.89^{\mathrm{A}}$ & 0.33 \\
\hline Total amino acid & 19.45 & 20.64 & 0.58 \\
\hline
\end{tabular}

1) Treatments are the same as in Table 2. ${ }^{2)}$ Pooled standard error $(n=3) . \quad$ 3) Flavorous amino acid;

4) Sweet taste amino acid; $\quad$ 5) Aromatic amino acid; $\quad$ 6) Bitter amino acid;

7) Essential amino acid.

A-B Means with different superscripts in the same column significantly differ at $\mathrm{p}<0.05$. 


\section{IV. 요 약}

경남 함양지방의 양돈장에서 사육중인 아메 리칸 버크셔종을 대상으로 산머루주 부산물을 배합사료와 혼합한 시험사료 $5 \%$ 를 20 두에 대 해 생시체중 $70 \mathrm{~kg}$ 에서 88일간 급여한 후 등심 부위를 채취하여 품질평가를 실시하였다. 일반 성분 분석결과 수분과 조지방은 대조구와 처리 구 간에 유의적인 차이를 나타내지 않았으나 $(\mathrm{p}>0.05)$, 조단백질과 조회분은 처리구가 낮았 다 $(\mathrm{p}<0.05) . \mathrm{pH}$ 와 $\mathrm{WHC}$ 는 대조구와 처리구 간 에 차이가 없었고 $(\mathrm{p}>0.05)$, 콜레스테롤과 지방 의 전단가는 처리구가 낮게 나타났다 $(\mathrm{p}<0.05)$. 육색은 차이가 없었으나 $(\mathrm{p}>0.05)$, 지방색에서의 명도와 백색도는 처리구가 높았다 $(\mathrm{p}<0.05)$. Oleic acid( $\left.\mathrm{C}_{18: 1}\right)$, linoleic acid (c18:2, n-6), arachidonic $\operatorname{acid}\left(\mathrm{C}_{20: 4,}, \mathrm{n}-6\right)$, 필수아미노산 및 $\mathrm{EFA} / \mathrm{UFA}$ 에서 유의적인 차이가 나타났다 $(\mathrm{p}<0.05)$. 총 아미노 산 함량은 대조구와 처리구 간에 유의적인 차 이가 없었으나 $(\mathrm{p}>0.05)$, 필수아미노산은 처리구 가 대조구 보다 높게 나타났다 $(\mathrm{p}<0.05)$. 이상에 서 산머루주 박 급여 시 등지방색, 전단가, 콜 레스테롤 및 필수지방산의 함량이 개선되는 것 으로 나타나 산업적 응용 가능성이 있을 것으 로 판단되었다.

\section{$\mathrm{V}$. 감사의 글}

본 논문은 경상남도 함양군의 지원에 의해 연구되었으며, 이에 감사드립니다.

\section{VI. 인 용 문 헌}

1. AOAC. 1990. "Official Methods of Analysis" 15th ed. Assosiation of Official Analytical Chemists. Washington, DC, USA.

2. Beuchat, L. R. and Golden, D. A. 1989. Antimicrobials occurring naturally in foods. Food Technol. 43:134-142.

3. Folch, J., Lees, M. and Sloan-Stanley, G. N.
1957. A simple method for the isolation and purification and purification of total lipides from animal tissues. J. Biol. Chem. 226:497.

4. Hwang, I. K. and Ahn, S. Y. 1975. Studies on of the anthocyanins in wild vines. J. Korean Agric. Shem. Soc. 18:188-193.

5. Jeremiah, L. E., Gibson, J. P., Gibson, L. L., Ball, R. O., Aker, C. and Fortin, A. 1999. The influence of breed, gender, and PSS(halothane) genotype on meat quality, cooking loss, and palatability of pork. Food Research International. 32:59.

6. Jin, S. K., Kim, I. S., Hur, S. J., Kim, S. J. and Jeong, K. J. 2006. The influence of pig breeds on qualities of loin. J. Anim. Sci. \& Technol. (Kor.). 48:747-758.

7. Joe, A. K., Liu, H., Suzui, M., Vural, M. E., Xiao, D. and Weinstein, I. B. 2002. Resveratrol induces growth inhibition, S-phase arrest, apoptosis, and changes in biomaker ewpression in several human cancer cell lines. Clin. Cancer Res. 8:893903.

8. Kim, S. K. 1996. Deacidification of new wild grape wine. Korean J. Food \& Nutr. 9:265-270.

9. Kim, Y. B., Rho, J. H., Richardson, I. and Wood, J. 2000. Comparison of physicochemical properties of pork from 4 different pig breeds. J. Anim. Sci. \& Technol. (Kor). 42(2):195.

10. Lan, Y. H., McKeith, F. K., Novakofski, J. and Carr, T. R. 1993. Carcass and muscle characteristics of Yorkshire, Meishan, Yorkshire $\times$ Meishan, Meishan $\times$ Yorkshire, Fenjing $\times$ Yorkshire, and Minzhu $\times$ Yorkshire pigs. J. Anim. Sci. 71: 3344.

11. Lee, S. K., Ju, M. K., Kim, Y. S., Kang, S. M. and Choi, Y. S. 2005. Quality cpmparison between Korean native black bround pork and modern genotype ground pork during refrigerated storage. Korean J. Food Sci. Ani. Resour. 25:7177.

12. Renaude, S. and Lorgeril, M. 1992. Wine, alcohol, platelets, and the French paradox for colony heart 
disease. Lancet. 339:1523-1526.

13. SAS. 1999. SAS/STAT Software for PC. Release 8.2, SAS Institute, Cary, NC, USA.

14. Wood. J. D., Richardson, R. I., Nute, G. R., Fisher, A. V., Campo, M. M., Kasapidou, E., Sheard, P. R. and Enser, M. 2004. Effect of fatty acids on meat quality: a review. Meat Sci. 66:2132.

15. 농촌진흥청 농촌생활연구소. 1991. 식품성분표 제6개정판. p.90.
16. 원지희, 손주아, 윤예리, 김호종, 김계원, 노봉수. 2006. 주박 첨가가 돈육의 품질특성에 미치는 영 향. 한국식생활문화학회지. 21(5):565-570.

17. 이문희, 김태완, 한일문, 강양수, 진상근, 김일석. 2005. 브랜드 돈육에 대한 경남 소비자 구매 특 성과 인지도. 한국축산식품학회지. 25(3):271-276.

18. 정인철, 문윤희. 2005. 머루주 박의 급여가 돈육 등심의 품질에 미치는 영향. 한국축산식품학회 지. 25(2):168-174.

(접수일자 : 2008. 1. 18. / 채택일자 : 2008. 4. 18.) 